\title{
MusEumS IN BRITAIN AND THE FIRST WORLD WAR
}

Gaynor Kavanagh

As an historian, genealogy has always worried me. I hold the Bible and the legal profession equally responsible for what is, after all, an obsession. Those who engage in genealogy usually have something to prove. They search for an unbroken lineage to someone worth being related to and, better still, important. Deviations along the way, such as illegitimacy, can be tolerated as long as they are sufficiently far in the past to be safe to mention. My problem with all this is that genealogy leaves out so much and asks so few questions. Real lives are about so much more than a series of 'begats' and 'begottens'. They are about choices made and not made, political change, feelings and circumstances. The genealogies of museums, like those of families, are equally problematic. They tend to be written from the inside, by museum people who have a vested interest in claiming a lineage and unblemished continuity. We have all read the texts, they tend to start with the Greek Muses take us through the Renaissance collections, genuflect at the Uffici Galleries in Florence, the Ashmolean Museum in Oxford and the British Museum and then rush on through a lengthy list of museums being founded, nodding here and there as they go at legislation passed or agreements made, and breathlessly reach the present day and the tidy bit of text which says THE END.

Other than giving us a slight sense of connectedness with colleagues now long departed and pointing to those museums for which respect is seen as a professional requirement, I am not sure how far such genealogies take us. They are usually stripped of the kinds of questions and research which lead to understanding. They neglect the political agendas of the day, the cultural codes under which peo- ple operated, the ideas, merits and inadequacies of those who governed or ran them. Furthermore, the experiences and opinions of visitors are regularly overlooked, as are those of the people whose former possessions on display. But, once we start looking at the primary sources, thinking about the contexts of provision and asking more penetrating questions, we discover that the histories of museums are 
40 full of discontinuities, ruptures and failures. How can we think it can be otherwise? Look at museums today, they are so diverse, so contradictory in what they are and what they are doing. They reflect and embody a whole range of agendas, ideals and politics: so too do museums in the past, and to ignore this impedes our understanding.

An alternative approach is to research not the history of a single museum, collection or discipline, but the history of museums within a particular period. In this way, we cannot avoid questions about context and how the development of museum provision related to prevalent social trends and political attitudes. Such an approach discloses that museums are not neutral places, nor are they without politics. Issues of class, gender, power, control and race are deeply imbedded in the history of museums. They hold the stories we tell ourselves about ourselves, and when the story changes - so do museums.

I elected to research the history of museums during the First World War for a number of reasons. One of them was that war exposes us for all that we are, all that we do, and all that we believe in. In particular, it tests the institutions and processes which are instruments of selfdefinition. It is little wonder that so many historical and religious places have been destroyed in Bosnia and Croatia - to change the political order, to engage in genocide - necessitates the destruction of all those things which help people define themselves: museums are on this list. So if we look at the histories of museums during wartime we have a very stark view of them. Indeed, the view is so stark it strips away all the comforts of history that museum professionals like so much. We are faced with the fundamentals of survival, change, and revision and are forced to look at museums, whether in peace or wartime, with new eyes.

One of the original aims of my research was to find out how museums survived the test of war, how they were used and how they contributed, and what was lost or gained by the experience. It was not enough just to consider what happened or did not happen in museums. I had to look at why things happened the way they did, the causes and the consequences. In this paper I would like to concentrate on what I consider to be the results or the outcomes of the experience of this war on museums in the Britain. But first a little context.

\section{MUSEUMS AND THE FIRST WORLD WAR}

In 1913, Elijah Howarth, curator of Sheffield museums, had been able to claim that 255 towns and villages outside the capital cities possessed museums. His count included university and private society museums, as well as municipal ones. On the eve of war, therefore, most major towns and cities in Britain boasted a museum. A significant proportion of these had been established in the previous two decades. By anyone's standards, this was a substantial growth in museum provision, of a kind not to be seen again until the heady days of museum expansion in the later 1970s. The museum boom of the 1890 s and 1900s lay the essential structure for museum provision in Britain. The provision of museums in the towns and 
MUSEUMS IN BRItain and The First World War

cities of Britain was a measure of the extent to which Britain in 1914 had become a primarily urban and industrial society, rich enough to support museums and willing to entertain the idea that such institutions would benefit the populace, $78 \%$ of whom now lived in towns.

On the eve of war, there was a pattern of museum provision, both at national and municipal levels, which had seen at least one generation of curators. The museum as a credential of civic status, scholarship or civilised nationhood still appeared to hold good, if investment in museum developments can be taken as an indicator, although museums were beginning to slip from the agenda of liberal politics. In the absence of consistent interest from outside, museum development had come to depend to a great degree upon the skills and attitudes of museum curators. A number of leading curators were trying to shape museum provision so that it might make a contribution towards moral, technical or art education; although many curators saw their role as being solely concerned with the research and well-being of the collections and had little concern about the visiting public.

The First World War changed everything and everything somehow came to bear it mark. In its way, the war brought the nineteenth century to an end and dictated the shape of the twentieth century. Further, the experience of war affected people in different ways. In the armed forces, a person's rank, the theatre of war in which he or she had been placed and the moment of involvement dictated in significant part the kind of memories held in later life. For those at home, whether working in munitions, on the land, in cle- rical work or in museums, the memories were of a different cast. Yet what bound most together was the profound experience of loss. And the losses were extreme: opportunities, hopes and dreams, ways of believing, and, of course, more than anything else - the lives of those known and loved. Perversely, the war also provided some positive gains, although even now these are hard to see, obscured as they are by the trauma of it all.

Throughout the war years, museum curators, and those who governed them, had attempted to do the right thing at the right time. This was by no means easy. There were significant swings in both public mood and political necessity during the four years of war, and what worked or was acceptable one year could be inappropriate the next. The responses made to the situation had to be carefully judged and in this museum curators were as much caught up in the train of events as were most people. The balance sheet in terms of what museums lost or gained in these years is not easy to lay out. This is partly because it is false to see the four years of war as being totally disconnected from pre- and post-war trends; partly because there was no such thing as a united museum movement, where what was true for one was true for all. But some general and specific points can be made.

\section{MUSEUMS AND THE PUBLIC}

It seems clear that the position of the national museums in the public's consciousness became even more secure. Arguably there was a deepening of the awareness of them as part of the apparatus which underpinned a broad cultural identity. In the midst 
42 of the crisis, the Britishness of the British Museum and the National Gallery was keenly felt, especially by the middle classes. These museums became one of a set of symbolic standards in the midst of beleaguered nationhood. In later years, Winston Churchill was alert to the importance of the great museums for national morale and in the 1930s refused to allow the National Gallery's collections to be taken out of the country for safety's sake. Unfortunately, during the early years of the First World War the importance of the national museums was not so readily recognised by the government who in 1916 insisted on their closure as a lesson to the nation on the economies to be expected in war time. Moreover, in 1917, it was rumoured that the Air Ministry was about to take over the British Museum, thereby making it a legitimate target. Public opinion had been seriously underestimated. The campaign to keep the national museums open was spontaneous and pursued with vigour. It perturbed even the press, itself not given to anything that might suggest even the mildest of criticisms of Governmental decisions and wary of anything that might 'rock the boat'. But in this instance the matter seemed clear: the decision to close the national museums was made for the wrong reasons, and the strength of public feeling had been underestimated.

Yet, in spite of the national museums and galleries in London being closed or partially closed from 1916 and the restrictions on the facilities available at a number of provincial museums, people were still disposed to visit those that remained open when they could. Given that Britain was engaged in a total war, the visitor figures for this period were noticeably high and therefore worthy of note. The relative consistency of these figures suggest that in the capital cities and in the provincial towns, museums must have been providing something that people needed: intellectually, socially or personally. Admittedly, museums were not universally adored, and significant social sectors may well have been indifferent to them or alienated by them. But, if anything the war may have, at least for a time, enhanced public attachment to them, by first threatening them with closure and worst still destruction, and second by giving them an opportunity to provide for the public in ways not considered before.

In the four years of war, many museums became centres for exhibitions, although these varied greatly in content. Some exhibitions sought to meet the mood of the moment, others to press for a suitably positive attitude or simply impart what was seen as important information. Whether about fleas, rats, feeding infants, growing potatoes, the plight of Belgian refugees, the weaponry of war, or the record of the war through contemporary paintings - all the exhibitions mounted had an underlying purpose: the war effort and its successful conclusion. In terms of museum practice, they provided ample evidence that museums could mount popular, instructive and socially useful exhibitions that would be well received and well attended. Such work involved curators in organising a range of material in an instructive manner, working in co-operation with others and engaging in supporting educational activities.

In terms of the war effort, it is impossible to gauge the degree to which such 

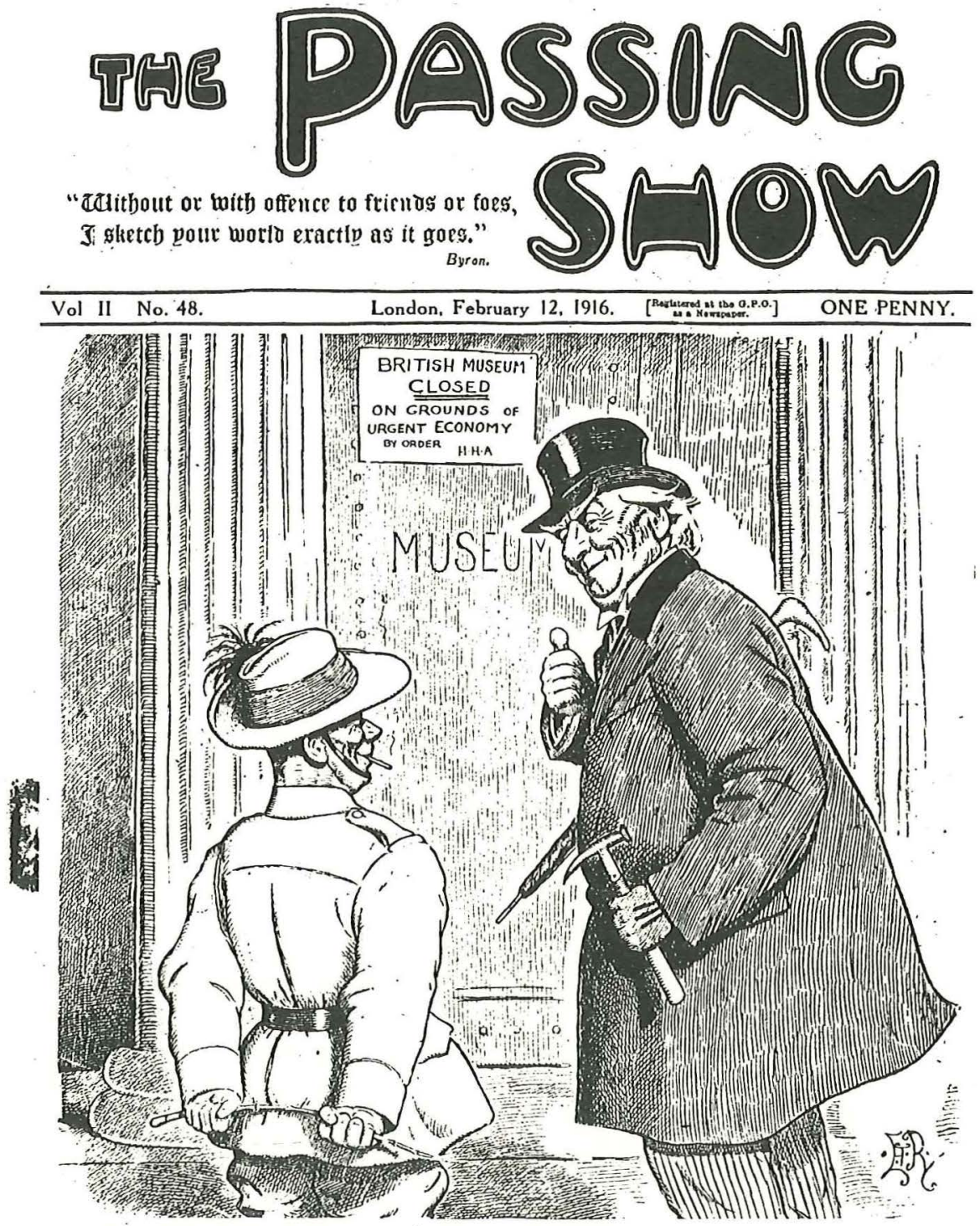

À NASTY ONE.

THE PRIME MINISTER: "M'yes, most interesting in peace time. - Full of ancient survivals and funny old relics of bygone times, but a most expensive and extravagant luxury in time of war, you know!"

Colonial (in London for the first time): "I see, Sir. Very much like the House of Commons, eh?"' 
44 exhibitions fulfilled the intentions of the authorities which funded and encouraged them. As has been seen, visitor figures for some of these exhibitions exceeded all expectations. But just because large numbers of people went to see the exhibitions, it does not necessarily follow that a uniform message was taken away by each and every single visitor, although the spirit of the thing may well have been consciously understood. Even today, when museums are equipped with a fairly sophisticated understanding of how visitors use the museum environment and can, to some degree, test whether the intentions behind an exhibition have been successful, it is impossible to gauge precisely its impact. We now recognise that people, within their given cultural and educational contexts, freely make up their own agendas when visiting exhibitions, and will pick and choose what they want to be interested in, and how much or little information they take away with them. There is nothing to suppose that in this regard visitors in 1918 were any different from visitors in 1993.

Suffice it to say that the confident belief that such exhibitions had been and were worthwhile, coupled with the educational work museums had developed with schools especially in Manchester, were enough to convince key figures in the Civil Service, Parliament and elsewhere that museums had a real educational purpose. The prewar rhetoric about the educational and social potential of museums had been tested and found to have in it more than a grain of truth. The view evolved that after the war museums could be developed to engage more directly in educational work and public service, but these propo- sals lapsed in the face of curatorial indifference and a failing post-war economy. However, what had been achieved was an important indicator that not only could museums cope in war-time, but that if appropriately employed, they could be both useful and advantageous on the home front, whether as part of the country's internal propaganda or as part of a search for rest and stability. For all the faults, shortcomings and inherent dangers, museums between 1914 and 1918, whether as sites for exhibitions or as homes for collections had something to offer.

\section{MUSEUMS \\ AND THEIR COLLECTIONS}

A development, which was to have long term benefits for museums, sprang unexpectedly from the risks of war. The problems of caring for major collections in such times, and especially the movement of collections to and from places of safety, sharply focused attention on the importance and condition of the material held. The collections from the national museums in London had to be removed in 1917 because of the increased risk from bombing and because all available space was needed for the administration of the war effort. One of the places of safety to which museum collections were sent was a section of London Underground. This was used by the British Museum, the National Gallery and the National Portrait Gallery, but unfortunately was environmentally unsuited to the well-being of most of the collections stored there. On the return of the material, a thorough audit was instigated: a cuneiform tablet once thought to have been lost was found. But of greater signi- 


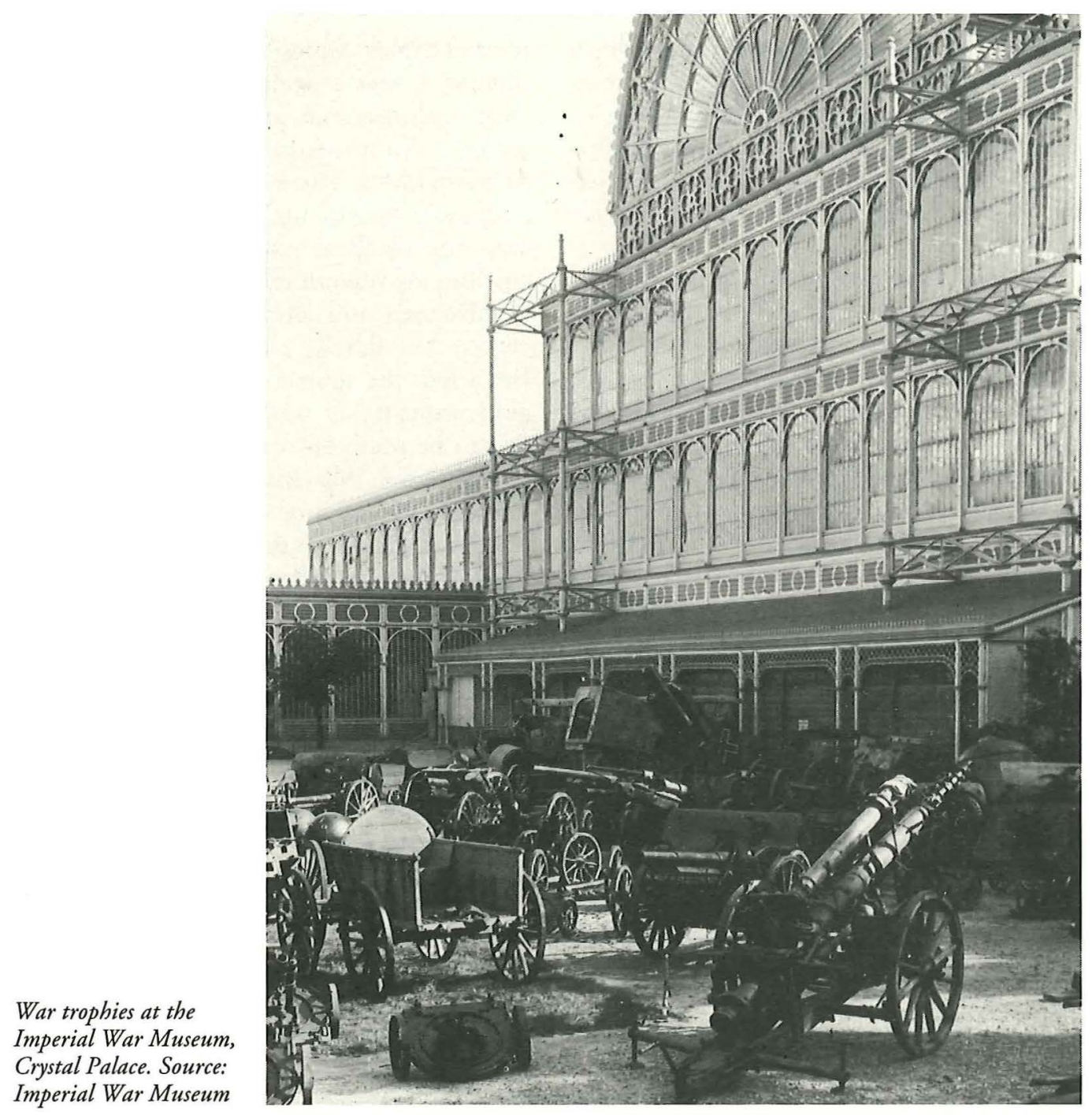

ficance, as a result of the movement of the collections, the British Museum and the National Gallery took steps to investigate the physical well-being of their holdings. This led ultimately to the founding of a scientific conservation department at the British Museum and leant considerable weight to the development of conservati- on facilities at the National Gallery and elsewhere. The new approaches to science in conservation successfully joined with the high levels of craft skill, which had been employed for some time in the restoration of materials. Better informed collection management at the nationals and, as the years progressed elsewhere, was a 
GAYNOR KAVANAGH

result. The conservation techniques developed in Britain, ongoing scientific research, and ever greater understanding of the importance of environmental conditions and handling procedures have resulted in Britain being a world leader in this field.

The political climate was ready for the promotion of the scientific conservation, in part at least because science itself was a beneficiary of war. It became popular and respectable in ways not experienced in the pre-war decades. As far as museums were concerned, the war gave ample opportunity for the science museums to prove their worth. The collections, research facilities and the expertise of curatorial staff came into use in unprecedented ways. Research undertaken at the British Museum (Natural History), the Geological Museum and the Science Museum contributed directly to the war effort. The reputations of these museums were enhanced as a result. Not only that, but in the post-war years, the heightened interest in science, amongst the public as much as official departments of state, ensured that these museums had a secured place. They adopted a positive attitude and were prepared to build on their success by expanding their services and experimenting with their exhibitions. Compared to other museums, they weathered the difficult years of the 1920s and 1930 s relatively well.

\section{A MUSEUM OF THE WAR}

One of the products of the war was the formation of a new national collection and museum: the Imperial War Museum. Regardless of the perspective taken of the war, as an evil mistake, an heroic adventu- re or complex conjoining of bitter circumstances, it was a profound human experience and deserved an adequate and full record. No museum has ever been established without some underlying political purpose. Sometimes if the subject is an easy one (such as water-colour paintings, costume or veteran cars), the purpose may be obscured and all those involved innocently, but falsely, claim their neutrality. But when the subject is hard (such as religion, industry or war), the political agenda can be more obvious. The founding of the Imperial War Museum was one of a range of initiatives taken to maintain a supportive attitude to the war at a moment when the country came near to defeat. The all-important immediate aim was balanced out by the long-term goals of those directly involved with the museum.

The adventurous approach adopted in the formation of the collections, and the comprehensiveness of record aimed for, ensured that the Imperial War Museum would find a role once the war ended. From the art collection, consisting of works commissioned from most of the leading artists of the day, to the debris of the battlefields, love letters, formal photographs, and uniforms worn by women conductors on London buses, the collections give an astonishingly vivid view of the war. Although beset by difficulties in the 1920s and 1930s, the museum's collection became, and remains, a principal source of reference to those studying the war. The fortunes of the museum fluctuated over the decades with each shift in public tolerance to the idea of war. It has emerged in the 1990s as a museum of international status, with well defined academic and educational roles. The com- 
plexities of interpretation and the balance between portraying war as heroics and war as human experience nevertheless remains.

\section{MUSEUMS IN \\ THE POST-WAR PERIOD}

Some post-war changes were unexpectedly enabling for museum developments. The shifts in world power, the continued rise of stronger centres of industrial and economic powers, particularly America and Japan, and the growing inability to cope with the demands of the Empire, resulted in a re-discovery of a domestic past. A regard for the countryside grew, as did enthusiasm for images of pre-industrial times: the view was often highly generalised and nearly always totally romanticised. Little wonder that in the 1920 s and 1930 s folk life collections and folk museums developed. Substantial progress was made in Scotland, Wales and the Isle of Man, where collections were formed and records gathered. Such broad based museum archives are now of considerable importance in our study of the cultural configurations of these areas and the daily lives of the people lived in them. In England, progress was far less assured and more sporadic. The strength of regionalism and, of greater importance, the lack of political necessity to define an English cultural whole, did not provide the conditions necessary for an English Folk Museum. In the absence of a national initiative, and for reasons mostly of their own, important regional folk collections were developed in a number of different locations in England. However, not until after the Second World War, when the Empire was being dismantled, did the folk life collection and museum become a common feature of museum provision throughout Britain.

The war had an impact on most forms of employment, including that in museums. Women came into curatorial work on a salaried basis. Some had to leave in 1919, but others did not and by the end of the 1920s, the idea of female museum curators was being accepted, although their subsequent rise to positions of seniority in museums has been very slow. There were other labour issues. During the war, museums especially the nationals and large provincial museums, became increasingly dependent on volunteers for tasks such as the packaging of collections for removal, with which the hard-pressed staff could not deal. The concept of volunteers in museums, either as helpers or as free curatorial labour, had been established in the late eighteenth century with the learned societies and was well developed in the nineteenth century in provincial museums. This did not change because of the war; indeed, if anything, it was reinforced by the war experience. Museums have always benefited from the talents and interests people elect to share with them. This form of participation undoubtedly has had its merits. But it has had many consequences for the development of professionalism and for the salary levels of museum posts, especially in the provinces. Museum authorities could and did pose the question: if able volunteers could carry out museum work, at least adequately and often very well, what need was there for the recruitment of young talented staff, or improved salaries in line with responsibilities?

Unfortunately, the war taught some les- 
48 sons which had to be remembered. When in the mid-1930s, it became increasingly likely that there would be another war, regardless of the manifestly empty reassurances to the contrary, curators and museum trustees had the experience of the First War to which they could refer. They knew a great deal about the movement of collections to places of safety, the securing of buildings, the use of museum space for Government and other departments, and the possible roles of museums in the maintenance of morale on the Home Front. The Second World War was different in so many ways from the First, it called for a much stronger response and, if anything, even greater endurance. In particular, the bomb damage was more extreme and geographically widespread, and a number of museums were either damaged or destroyed. The British Museum and the Tate were badly hit. Liverpool and Hull museums lost a substantial part of their buildings and also major collections. The Victoria and Albert Museum, on the wall nearest the entrance to the Henry Cole Wing, still bears scars from the Blitz. It is impossible to calculate how much greater the losses would have been had not the museums been aware of the risks and taken appropriate action. If the national museum and gallery collections had remained on view in London, it is highly likely they would have been either destroyed or damaged.

\section{REMEMBERING}

So far I have outlined what might be seen as positive or enabling outcomes of the war experience. There were of course a number which were very negative indeed.
Of the three quarters of a million British men who lost their lives in the war, a very small number were men who worked in museums and who no doubt believed they would return to such work when the war was over. A number of museums, including the British Museum and the Natural History Museum, installed memorials to their staff members killed on active service. It is impossible to calculate the loss of talent this represented, nor the losses which accrued from the deaths of younger men who, once their university or technical education was completed, might have come into curatorial work. The Lost Generation could have made a world of difference had they survived to experience the bulk of the twentieth century, or so we tend to think. Of those that did survive the war, the scars were often as much on the personality and memory, as over the body. Healing was about much more than the repair of bone and body tissue.

The dead had to be remembered in a way which was fitting and which helped the living grieve. Even before the war ended there were a number of proposals about how this might best be achieved. One of them involved the suggestion that every city, town and village should have a war museum. Even before the war ended in November 1918, this proposal was no longer taken seriously. Other ways of remembering were found: people needed the quiet dignity of the memorials and memorial gardens, and positive contributions to the lives of those left, such as memorial hospitals and recreation grounds. The broken bodies of ex-service men were everywhere to be seen, and the broken lives of those who had lost someone very close escaped no-one. As time 
went on people became less inclined to look upon the facts and mementoes of war. The Imperial War Museum filled certain needs as far as they went, but at local level things were different. In these circumstances, it is as well that local museums devoted to the war were not established. Not only would they have been out of tune with a nation in grief, but also, more practically, the cost and the responsibility for their development might have resulted in the over-burdening of local authority museum services to the point of collapse. For the inter-war years, the local authorities had difficulty enough financing essential services such as children's education, let alone established museum services. Museums outside London managed to keep going somehow: the status quo was maintained, more or less. However, there was simply no money for new museums and it would have been impossible to establish and sustain local war museums in such circumstances.

In contrast, there was a very noticeable increase in the number of service, especially regimental, museums and collections. By the end of the inter-war period as many as fifty regimental museums were founded, although they were developed for a variety of reasons. The common factor, however, was that their purpose was not directed outwards to the general public, but inwards to the services' own needs. For some regiments, the exercise may well have been pragmatic; for others, much more deliberate and conscious. However, for the first time ever, important material was brought together from a variety of 'lodging' places and identified as worthy of the type of care given in museums. The service museums, the majority embryonic, struggled on as best they could well into the 1950 s. In the past forty years, some have managed well enough, but others, perhaps the majority, have stagnated. This can be ascribed in part to the fact that in the critical period of their early development, that is in the inter-war years, there was not sufficient political or social purpose to facilitate their growth and hence funds were not made available for them.

\section{CURATORS AND MUSEUMS: NEW AGENDAS?}

In the early 1920s, with the economy in disarray and far-reaching social problems to cope with, the Government no longer had a place for museums, of any sort, on their political agenda. A great deal of museum work in the war had indicated the potential of both well-thought out collections and exhibitions timed to meet people's interests. Many people, including a number of politicians, were convinced, but even this was not sufficient in such hard times. Established on the Victorian philosophy of self-help and the moral purposes of education, museums were left in the hands of underpaid, untrained and ageing curators. Certainly, there were people of calibre employed in museums; for example, from the war period itself Elijah Howarth, curator of Sheffield Museum, and Frederic Kenyon, Director of the British Museum, stand out. But there were many, many others - weary men, in need of both rest and retirement. More than adequately conversant with the well-articulated philosophies of museum provision, a good part of which they had help develop, they had not the stamina, the resources or the attitudes necessary to 
50 produce the form of provision needed in the 1920s and 1930s. A good proportion of museums survived the inter-war period in the relative security of stagnation, which the curators did little to disturb.

The museums which prospered during this time were those where relevant scholarly work was conducted and where efforts were made to interpret collections in interesting ways. The Science Museum is a case in point. Here, much good, solid academic work was conducted and collections of importance were acquired. But the majority failed to shake off their reputation for being dusty places where dead objects rested. This did not go unnoticed. For example, a Board of Education Report in 1931, paid warm tribute to the richness and variety of museum collections, but pointed out that large sums of public money were being spent on them and that they were not being used 'as they could or should be in the service of education'.

Underlying this was the failure of curators, especially those who spoke on behalf of the majority, to grasp the importance of what had been achieved in the war and to adapt the ideas and methods for use in peacetime. There was more than enough here to argue a convincing case for enhanced museum provision. But, instead, temporary exhibitions addressing current interests and public education were largely abandoned, there was a reluctance to accept fully the educational roles of museums, and an inability to see how the precedent of contemporary collecting at the Imperial War Museum might be adapted and used elsewhere. This inability to learn from the war experience set-back museum provision at a time when it could be ill afforded. Several generations later, these ideas were discovered all over again and are in use today.

In so many respects, the case for museums in the 1990s would be all the stronger had not momentum been lost in the 1920s. Admittedly, curators knew there was a problem, hence the efforts throughout the 1920 s to establish some system of professional training. But much more was needed; in particular, open minds, a willingness to learn and an ability to see the world as it was: in a state of rapid change. Museums had proven their usefulness in the war, but in times of peace their purposes became much less certain. It took another war and a new generation of curators before different ideas were allowed to prevail.

\section{Gaynor Kavanagh är lärare vid Department of} Museums Studies, Leicester University. Hon har bl a skrivit boken History Curatorship och redigerat flera av institutionens skrifter.

Adr: Department of Museum Studies, University of Leicester, 105 Princess Road East, Leicester LE1 7LG, England, FAX +44533523960 .

\section{NOTE}

This paper is based upon the text of the penultimate chapter in Museums and the First World War which will be published by Leicester University Press in March 1994. The author will be glad to answer any questions about the sources used and to receive suggestions for alternative lines of research. 